\title{
Characterization of Nematode Infestation on Parachanna obscura (Gunther, 1861) (Channidae) and Infection in the Blood
}

\author{
Paul Onu Ajah ${ }^{1, *}$, Efio-Okon Bassey Ita $^{1}$, Nneka Love Allison $^{1}$ \\ ${ }^{1}$ University of Calabar, Faculty of Oceanography, Calabar, Nigeria.
}

\section{Article History}

Received Feb 25, 2020

Accepted Jun 5, 2020

First Online Jun 5, 2020

\section{Corresponding Author}

Tel.: +2348033707901

E-mail: ajapaulo60@gmail.com

\section{Keywords}

P. obscura

Prevalence

Haematology

Aquaculture

Nematode

Fish health

\begin{abstract}
Parachanna obscura commands high food value and quite critical in the control of tilapia population in ponds. The health status of fish is assured upon proper diagnosis of the blood parameters. Research on fifty $P$. obscura from Great Kwa River, Nigeria investigated, showed 24 (48\%) were infested with nematode and infected the blood while 26 (52\%) were not. The mean blood Pack cell volume (PCV), Lymphocyte, Monocyte, Leucocyte, Neutrophils, and Eosinophils for infected(non-infested) $P$. obscura respectively were $20.8 \%$ (21.6\%); $44.4 \%$ (39.3\%); $1.9 \%(1.92 \%) ; 4.18 \times 10^{3} \mathrm{~mm}$ ${ }^{3}\left(4.48 \times 10^{3} \mathrm{~mm}^{-3}\right), 51.7 \%(57.5 \%)$. and $1.58 \%(1.2 \%)$. No positive correlation existed between infested and non-infested. The lower PCV, Leucocyte, and Neutrophils are indications of lower immunity. Prevalence rate increased with size from $26 \%$ (22$26.9 \mathrm{~cm}), 56.5 \%(27-31.9 \mathrm{~cm})$ to $66.7 \%$ at class range $32-36.9 \mathrm{~cm}$, while Incidence of infestation decreased with increase in length, $2.75,2.25$ and 2.0 respectively for 22 $26.9 \mathrm{~cm}, 27-31.9 \mathrm{~cm}$ and $32-36.9 \mathrm{~cm}$. The class $12-16.9 \mathrm{~cm}$ did not follow any pattern. The parasitic burden occurred at the weaker/more vulnerable part-anal pore (61.7\%), followed by fish intestine $(29.8 \%)$, cardiac $(4.3 \%)$ and caecum $(4.3 \%)$. The mean physicochemical parameters of the study area across the three tidal intervals ranged from $5.11 \pm 0.04-6.72 \pm 0.00$ for $\mathrm{pH}$, conductivity $18.70 \pm 0.20 \mu \mathrm{S}-37.95 \pm 1.05 \mu \mathrm{S}$, dissolved oxygen $2.60 \pm 0.00 \mathrm{mg} / \mathrm{l}-4.00 \pm 0.60 \mathrm{mg} / \mathrm{l}$, temperature $25.50 \pm 0.50^{\circ} \mathrm{C}-27.00 \pm 0.00^{\circ} \mathrm{C}$, salinity $0.01 \pm 0.00 \mathrm{mg} / \mathrm{l}-0.03 \pm 0.01 \mathrm{mg} / \mathrm{l}$ and total dissolved solid (TDS) $23.19 \pm 0.25 \mathrm{mg} / \mathrm{l}-$ $47.06 \pm 1.30 \mathrm{mg} / \mathrm{l}$.
\end{abstract}

\section{Introduction}

Parachanna obscura popularly known as snakehead belongs to the family channidae and is commonly found in natural freshwater/swamp of the southern part of Cross River State. It inhabits lowland rivers, streams, creeks, swamps, canals, lakes and ponds (Teugels, Breine \& Thys van der Audernaede, 1984; Guseva, 1990; Teugels, Reid \& King, (1992). This species of fish constitutes a highly cherished member of the fish community in Cross River State, Nigeria and Bangladesh with superb taste and high-quality flesh which commands a high market value (Ama-Abasi \& Anthony, 2010; Akther, Hakkani, Moni, \& Mohanta, 2018). In fish culture, $P$. obscura exhibits an enormous potential in Tilapia sp. population control being a voracious predator (Bassey \& Ajah, 2010). According to Satheeshkumar, Ananthan, Senthil, Kumar, and Jagadeesan, (2010); Pradhan, Patra, and Pal, (2014), the use of haematological parameters in diagnosing the state of 
health of natural fish is gaining worldwide acceptance as a tool in the management of fish both in the natural and artificial environment. Changes in haematological parameters due to infection by parasites such as nematodes are one of the indices of the ill health of the fish (Clauss, Alistair, \& Arnold, 2008; Adeyemo, Okwilagwe, \& Ajani., 2009). The parasitic form of nematodes lives in the host gut, blood (e.g Wucheria bancrofti, Loa loa, Onchorcercia volvolus and Dracunculus sp. as well as other filarial hosts), tissue nematodes (Trichurius spirasis), intestinal nematodes (T. trichuriae), and lymph vessels most of which are macroscopic (Conver, Spadling, \& Forester, 2003). The parasitic infection of fish leads to economic losses due to not only mortality but also treatment costs, decreasing growth that reduces the expansion of aquaculture (Akther, Hakkani, Ashaduzzaman \& Mohanta, 2017; Gado, Mahfouz, Moustafa, \& Lolo, 2017; Oladipo, Sunday \& Ogunbiyi, 2019). Diseases caused by parasites make fish culturing a high-risk investment (Kumari \& Perven, 2017). Stress in fish may be induced by both biotic and environmental factors (Labello, Saunder, \& Crawford, 2001; Witeska, 2005; Ahmed \& Sheikh, 2020). Ajah and Ukutt (2018 a, b) observed that water soluble fraction from crude oil can stress a fish and lead to alteration of the haemotological characteristics of starved or fed catfish. This study therefore analysis the blood of infested and non-infested $P$. obscura as a tool to determine its state of health and the aquacultural implications following Kori-Siakpere and Egbor (1997; Kori-Siakpere, Ake, \& Idoge, 2005).

\section{Materials and Methods}

\section{Study Area}

Fifty life specimens of the African Snakehead, Parachanna obscura were obtained from the Great Kwa
River (a tidal river) within the Esuk Mba axis of the Akpabuyo Local Government Area of Cross River State, Nigeria. The Great Kwa River covers a distance of $60 \mathrm{~km}$ in length and an average of $1.66 \mathrm{~km}$ in width. It lies along latitude $8.22^{\circ} \mathrm{N}$ and Longitude $4.45^{\circ} \mathrm{E}$.

\section{Physicochemical Parameters of Esuk Mba Water for the Three Tidal Cycles}

The mean results from analyses of different water quality parameters carried out in the study area at different tidal intervals are as follows: the mean $\mathrm{pH}$ ranged between $5.11 \pm 0.04$ to $6.72 \pm 0.00$, Conductivity $18.70 \pm 0.20 \mu \mathrm{S}$ and $37.95 \pm 1.05 \mu \mathrm{S}$, Dissolved Oxygen $2.60 \pm 0.00 \mathrm{mg} / \mathrm{l}$ to $4.00 \pm 0.60 \mathrm{mg} / \mathrm{l}$, water temperature range from $25.50 \pm 0.50^{\circ} \mathrm{C}$ to $27.00 \pm 0.00^{\circ} \mathrm{C}$, Salinity level wasn't lower than $0.01 \pm 0.00 \mathrm{mg} / \mathrm{l}$ nor higher than $0.03 \pm 0.01 \mathrm{mg} / \mathrm{l}$ and Total dissolved solid (TDS) ranged between $47.06 \pm 1.30 \mathrm{mg} / \mathrm{l}$ and $23.19 \pm 0.25 \mathrm{mg} / \mathrm{l}$. across the tidal intervals.

\section{Fish Samples}

Fifty (50) samples of $P$. obscura (Figure 1 ). were caught by means of fish trap and put in aerated containers for onward transportation to the Zoology and Environmental Biology Laboratory, University of Calabar, Nigeria. The samples were stored in two reinforced plastic water tanks of 200 l capacity each for a minimum of two (2) weeks following Gupta and Banerjee (2011). During this period, they became adjusted to the laboratory conditions and were fed with artificial (pelleted) feeds and ground shrimps obtained locally to avoid possible distortion of the haematological parameters due to effect of starvation. The fish were weighed using Kitchen scale (Model: Ashton Meyers Scale $0.1 \mathrm{~g}-5 \mathrm{~kg}$ ) and recorded in grams (g). A metre rule was used to measure the length in centimeters $(\mathrm{cm})$

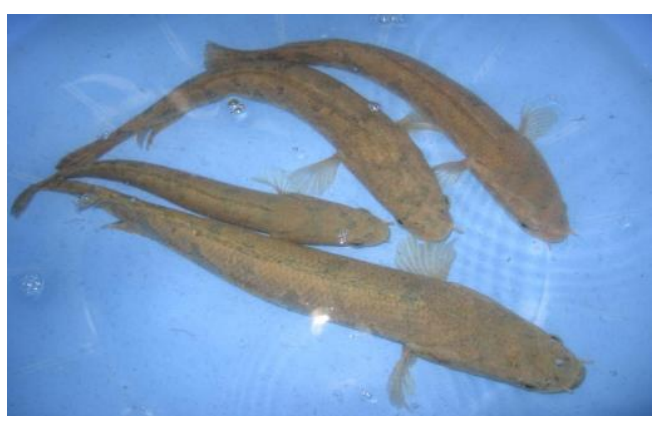

Figure 1. Acclimatization of Parachanna obscura in the tank

Table 1. Prevalence and incidence of Nematode infestation in Parachanna obscura

\begin{tabular}{lccccc}
\hline $\begin{array}{l}\text { Length } \\
\text { class }\end{array}$ & $\begin{array}{c}\text { Sample size } \\
(\%)\end{array}$ & $\begin{array}{c}\text { obscura } \\
\text { infested (\%) }\end{array}$ & $\begin{array}{c}\text { Nematodes in Infested } P \text {. } \\
\text { obscura }\end{array}$ & $\begin{array}{c}\text { Incidence of } \\
\text { infestation }\end{array}$ & $\begin{array}{c}\text { Prevalence per class (\%) /Total } \\
\text { population (\%) }\end{array}$ \\
\hline $12-16.9$ & $1(2)$ & - & - & & - \\
$17-21.9$ & $5(10)$ & $3(12.5)$ & 4 & 1.33 & $60(8)$ \\
$22-26.9$ & $15(30)$ & $4(16.7)$ & 11 & 2.75 & $26.7(22)$ \\
$27-31.9$ & $23(46)$ & $13(54.17)$ & 26 & 2.25 & $56.5(52)$ \\
$32-36.9$ & $6(12)$ & $4(16.7)$ & 9 & 2.0 & $66.7(18)$ \\
\hline
\end{tabular}


from the snout to the caudal fin. In similar experiment, Jerônimo, et al., (2014) used 60 fish, 30 per season to investigate the haematological and histopathological parameters in South American fish Piaractus mesopotamicus parasitized by monogenean (Dactylogyridae) while Mazumder, Fivelstad, Ghaffar, and Das (2019) analyzed theirs using 40 blood specimens of juvenile snapper fish (Lutjanus molabaricus).

\section{Blood Collection}

The fish was anaesthetized with MS-222 (Imanpoor, Bagheri \& Hedayati, 2010) before the fish belly was placed upward. Blood samples were obtained from the lamellae around the gill arch with the aid of a heparinized $2 \mathrm{~cm}^{3}$ disposable plastic syringes (Figure 2) and 21-gauge disposable hypodermic needle as described by Lavanya, Ramesh, Kavitha, and Malarvizhi (2011). The use of the blood plastic syringe is a necessary precaution with fish blood because contact with glass results in decreased coagulation (Smith Lewis \& Kaplan, 1952). The site chosen for puncture was thoroughly wiped dry with tissue paper to avoid contamination with mucus. The needle was inserted directly to where the gills originate from and was gently aspirated during penetration (Figure 2). It was then pushed gently down until blood started to enter as the needle punctured the blood vessel. Blood was taken until about $2 \mathrm{ml}$ has been obtained. Thereafter, the needle would be withdrawn, and the blood gently transferred in heparinized specimen (EDTA) bottles (Lavanya, et al., 2011) shown as Figure 3 and 4 to act as anti-coagulant; the samples were then mixed gently but thoroughly. Some blood samples were used for the measurement of packed cell volume (PCV), white blood cell count (WBC), Erythrocyte count and Leucocytes count.

\section{Blood Analysis}

Red blood cells (RBC) count was done on blood samples appropriately diluted with Hayem's fluid in RBC diluting pipette. The method described by Lewis and Ward (1975) was adopted. A 1:20 blood sample dilution was discharged into the improved Neubauer chamber

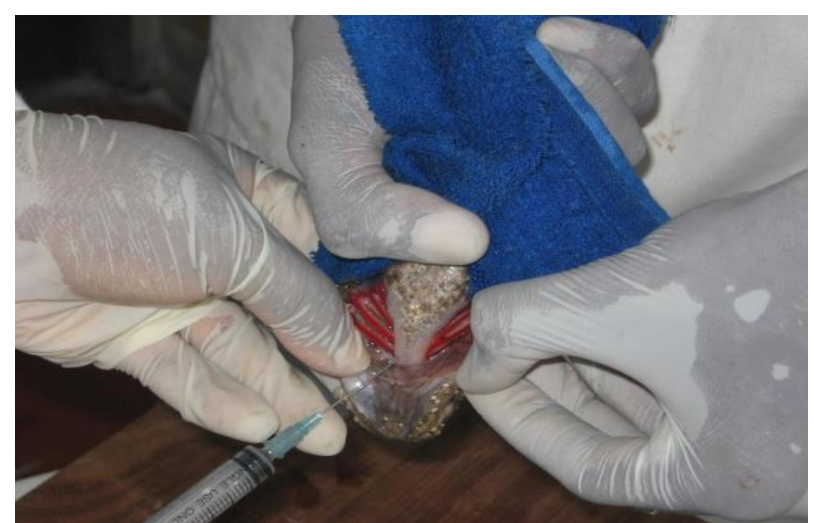

Figure 2. Removing blood using a hypodermic needle

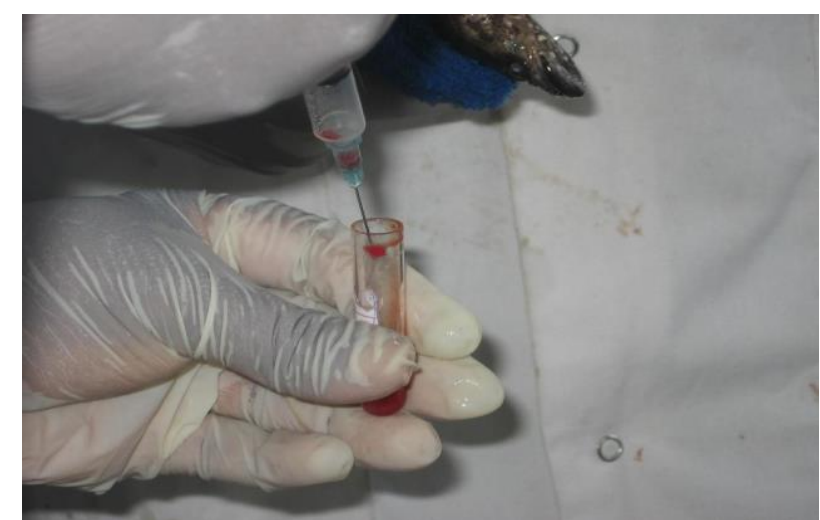

Figure 3. Introduction of Parachanna obscura blood in specimen bottles

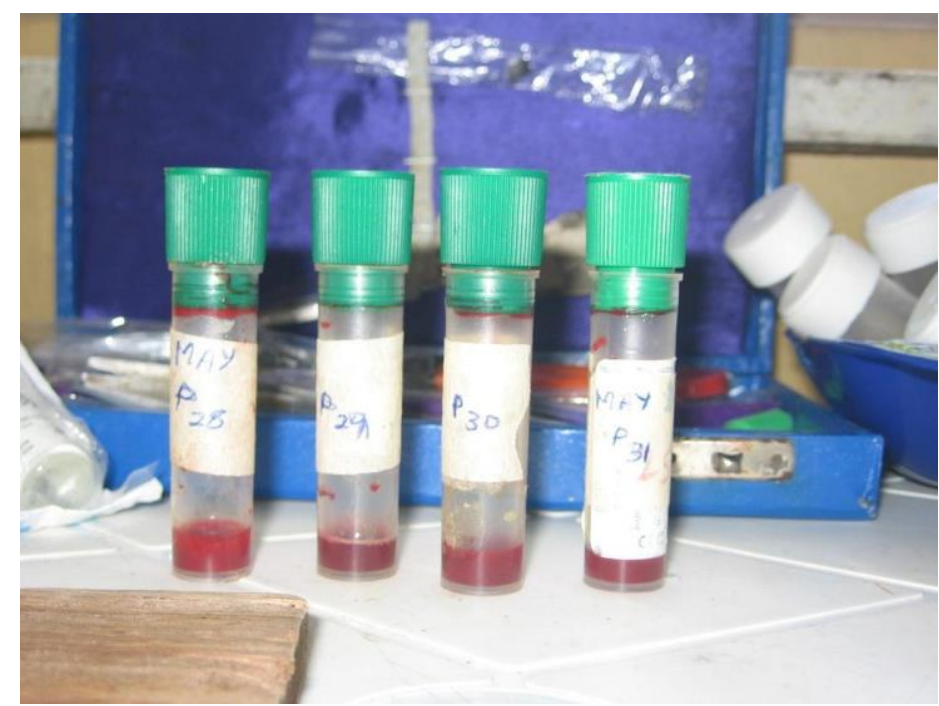

Figure 4. Parachanna obscura blood in well labeled specimen bottles 


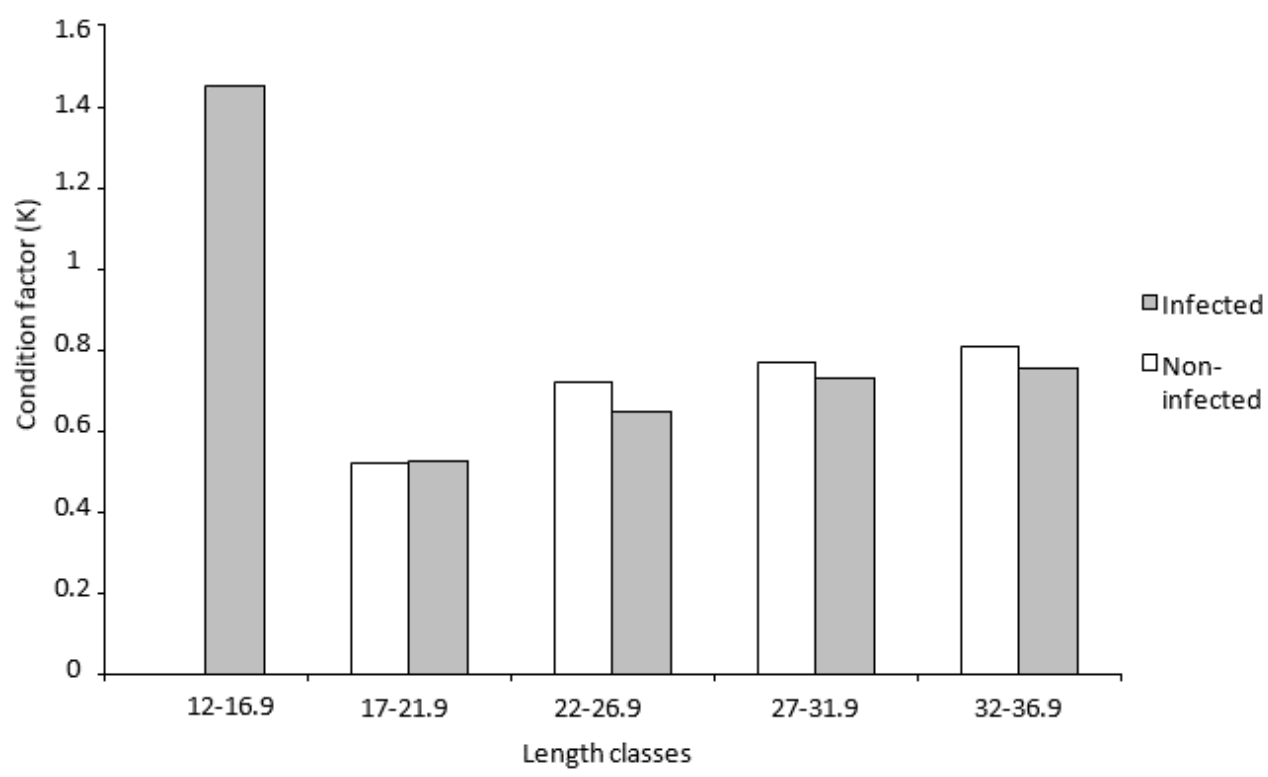

Figure 5. Mean condition factor for infested and non-infested Parachanna obscura

and viewed with a light microscope. The cells were counted using $\times 40$ magnification with observation of the margin rule.

White blood cells (WBC) count was done in a manner similar to RBC count. Blood samples were diluted (1:20) with Turk's fluid and introduced into the chamber and counted. The numbers of cells/ $\mathrm{mm}^{3}$ were obtained by multiplying by 50 (Dacie \& Lewis, 1984).

The capillary tube was $2 / 3$ filled with anticoagulated blood and spinned at 12,000 g for 5 minutes using micro-haematocrit centrifuge. The PCV was read using micro-haematocrit reader as a percentage following Adebayo, Fagbenro, Ajayi, and Popoola (2007).

$0.02 \mathrm{ml}$ of sample was placed in Sahli's tube $(90-$ $140 \mathrm{~g} / \mathrm{dl}$ ) holding $0.1 \mathrm{~N} \mathrm{HCL}$ in its 1in unit mark and allowed to stand for 5 minutes. The brown precipitate acid-hamatin was developed to match the unfading standard colour (Dacie \& Lewis, 1984). The volume of the solution in the graduated Sahli's tube was then converted to haemoglobin concentration in $\mathrm{g} / \mathrm{dl}$. The haematological indices included the following; mean packed cell volume (PCV), mean leucocyte, mean Eosinophills, mean Neutrophills calculated from the equations given by Anderson and Klontz (1965).

\section{Statistical Analysis}

The following parameters were calculated following Margolis, Esch, Holmes, Kuris and Schad (1982) as adopted by Akther, et al (2017):

Prevalence per size group; No. of host infested in the class $\times 100$ Total No. of host in the class

Prevalence per population; No. of parasites in the class $\times 100$
Total No. of host examined

Incidence of infestation;

Number of parasites

Number in the host class infested

Condition factor (CF); $\frac{100 p}{L^{3}}$

$\mathrm{L}^{3}$

where: $P$ is weight $(g), L$ is length $(\mathrm{cm})$

IBM SPSS Statistics 20 software package was used to (1) compare the means using ANOVA and test of linearity to determine the level of homogeneity and skewness at $\alpha=0.05$ level test, and (2) determine the coefficient of correlation of parameters between infested and non-infested Parachanna obscura at 0.05 and 0.01 level of significant.

\section{Co-efficient of correlation r; $\sum(x-x)(y-y)$ $v \sum(x-x) 2 \sum(y-y)^{2}$}

\section{Results and Discussion}

A total of fifty (50) fishes were examined and the size ranges taken as well as the frequencies of occurrence in relation to size variation are as shown in Table 1. The specimens were divided into five (5) size groups ranging from $12 \mathrm{~cm}$ to $37 \mathrm{~cm}$. There was a preponderance of specimens with standard length ranging from $22 \mathrm{~cm}$ to $32 \mathrm{~cm}$ over others accounting for $88 \%$ frequency of the total population of specimens examined (Table 1).

All size groups were examined for nematode infestation and a total of twenty-four or $48 \%$ of the Parachanna were infested while twenty-six or $52 \%$ were 
Table 2. Combined Correlations coefficients of the haematological parameters between infested and non-infested P. Obscura

\begin{tabular}{|c|c|c|c|c|c|c|c|c|c|c|c|c|c|}
\hline & & Leu1 & Leu2 & PCV1 & PCV2 & Neu1 & $\mathrm{Neu} 2$ & Lym1 & Lym2 & Mono1 & Mono2 & Eosino1 & Eosino2 \\
\hline & Pearson Correlation & 1 & -.345 & .262 & .370 & $.515^{*}$ & -.064 & $-.452^{*}$ & .075 & -.371 & .053 & .171 & -.163 \\
\hline \multirow[t]{3}{*}{ Leu1 } & Sig. (2-tailed) & & .099 & .215 & .075 & .010 & .768 & .027 & .727 & .075 & .806 & .423 & .447 \\
\hline & $\mathrm{N}$ & 24 & 24 & 24 & 24 & 24 & 24 & 24 & 24 & 24 & 24 & 24 & 24 \\
\hline & Pearson Correlation & -.345 & 1 & -.225 & -.109 & -.069 & $.389^{*}$ & .085 & $-.423^{*}$ & -.176 & .023 & -.119 & .239 \\
\hline \multirow[t]{3}{*}{ Leu2 } & Sig. (2-tailed) & .099 & & .292 & .596 & .749 & .049 & .692 & .031 & .411 & .909 & .580 & .240 \\
\hline & $\mathrm{N}$ & 24 & 26 & 24 & 26 & 24 & 26 & 24 & 26 & 24 & 26 & 24 & 26 \\
\hline & Pearson Correlation & .262 & -.225 & 1 & .033 & .343 & .113 & $-.408^{*}$ & -.104 & .028 & .087 & .309 & -.159 \\
\hline \multirow[t]{3}{*}{ PCV1 } & Sig. (2-tailed) & .215 & .292 & & .880 & .101 & .599 & .048 & .628 & .895 & .686 & .142 & .459 \\
\hline & $\mathrm{N}$ & 24 & 24 & 24 & 24 & 24 & 24 & 24 & 24 & 24 & 24 & 24 & 24 \\
\hline & Pearson Correlation & .370 & -.109 & .033 & 1 & .351 & $-.410^{*}$ & -.335 & $.419^{*}$ & -.318 & .198 & .148 & -.244 \\
\hline \multirow[t]{3}{*}{ PCV2 } & Sig. (2-tailed) & .075 & .596 & .880 & & .093 & .038 & .110 & .033 & .130 & .332 & .489 & .230 \\
\hline & $\mathrm{N}$ & 24 & 26 & 24 & 26 & 24 & 26 & 24 & 26 & 24 & 26 & 24 & 26 \\
\hline & Pearson Correlation & $.515^{*}$ & -.069 & .343 & .351 & 1 & .109 & $-.960^{* *}$ & -.090 & -.256 & -.254 & .291 & .124 \\
\hline \multirow[t]{3}{*}{ Neu1 } & Sig. (2-tailed) & .010 & .749 & .101 & .093 & & .611 & .000 & .675 & .227 & .231 & .167 & .564 \\
\hline & $\mathrm{N}$ & 24 & 24 & 24 & 24 & 24 & 24 & 24 & 24 & 24 & 24 & 24 & 24 \\
\hline & Pearson Correlation & -.064 & $.389^{*}$ & .113 & $-.410^{*}$ & .109 & 1 & -.098 & $-.986^{* *}$ & -.038 & -.224 & -.225 & .113 \\
\hline \multirow[t]{3}{*}{ Neu2 } & Sig. (2-tailed) & .768 & .049 & .599 & .038 & .611 & & .647 & .000 & .860 & .271 & .291 & .582 \\
\hline & $\mathrm{N}$ & 24 & 26 & 24 & 26 & 24 & 26 & 24 & 26 & 24 & 26 & 24 & 26 \\
\hline & Pearson Correlation & $-.452^{*}$ & .085 & $-.408^{*}$ & -.335 & $-.960^{* *}$ & -.098 & 1 & .081 & .236 & .206 & $-.479^{*}$ & -.092 \\
\hline \multirow[t]{3}{*}{ Lym1 } & Sig. (2-tailed) & .027 & .692 & .048 & .110 & .000 & .647 & & .708 & .267 & .333 & .018 & .668 \\
\hline & $\mathrm{N}$ & 24 & 24 & 24 & 24 & 24 & 24 & 24 & 24 & 24 & 24 & 24 & 24 \\
\hline & Pearson Correlation & .075 & $-.423^{*}$ & -.104 & $.419^{*}$ & -.090 & $-.986^{* *}$ & .081 & 1 & .066 & .122 & .236 & -.218 \\
\hline \multirow[t]{3}{*}{ Lym2 } & Sig. (2-tailed) & .727 & .031 & .628 & .033 & .675 & .000 & .708 & & .759 & .553 & .267 & .285 \\
\hline & $\mathrm{N}$ & 24 & 26 & 24 & 26 & 24 & 26 & 24 & 26 & 24 & 26 & 24 & 26 \\
\hline & Pearson Correlation & -.371 & -.176 & .028 & -.318 & -.256 & -.038 & .236 & .066 & 1 & $-.481^{*}$ & -.292 & .216 \\
\hline \multirow[t]{3}{*}{ Mono1 } & Sig. (2-tailed) & .075 & .411 & .895 & .130 & .227 & .860 & .267 & .759 & & .017 & .166 & .310 \\
\hline & $\mathrm{N}$ & 24 & 24 & 24 & 24 & 24 & 24 & 24 & 24 & 24 & 24 & 24 & 24 \\
\hline & Pearson Correlation & .053 & .023 & .087 & .198 & -.254 & -.224 & .206 & .122 & $-.481^{*}$ & 1 & .199 & -.237 \\
\hline \multirow[t]{3}{*}{ Mono2 } & Sig. (2-tailed) & .806 & .909 & .686 & .332 & .231 & .271 & .333 & .553 & .017 & & .352 & .243 \\
\hline & $N$ & 24 & 26 & 24 & 26 & 24 & 26 & 24 & 26 & 24 & 26 & 24 & 26 \\
\hline & Pearson Correlation & .171 & -.119 & .309 & .148 & .291 & -.225 & $-.479^{*}$ & .236 & -.292 & .199 & 1 & -.249 \\
\hline \multirow[t]{3}{*}{ Eosino1 } & Sig. (2-tailed) & .423 & .580 & .142 & .489 & .167 & .291 & .018 & .267 & .166 & .352 & & .242 \\
\hline & $N$ & 24 & 24 & 24 & 24 & 24 & 24 & 24 & 24 & 24 & 24 & 24 & 24 \\
\hline & Pearson Correlation & -.163 & .239 & -.159 & -.244 & .124 & .113 & -.092 & -.218 & .216 & -.237 & -.249 & 1 \\
\hline \multirow[t]{2}{*}{ Eosino2 } & Sig. (2-tailed) & .447 & .240 & .459 & .230 & .564 & .582 & .668 & .285 & .310 & .243 & .242 & \\
\hline & $\mathrm{N}$ & 24 & 26 & 24 & 26 & 24 & 26 & 24 & 26 & 24 & 26 & 24 & 26 \\
\hline
\end{tabular}

*. Correlation is significant at the 0.05 level (2-tailed). 1 rep infested and 2 non-infested.

**. Correlation is significant at the 0.01 level (2-tailed).

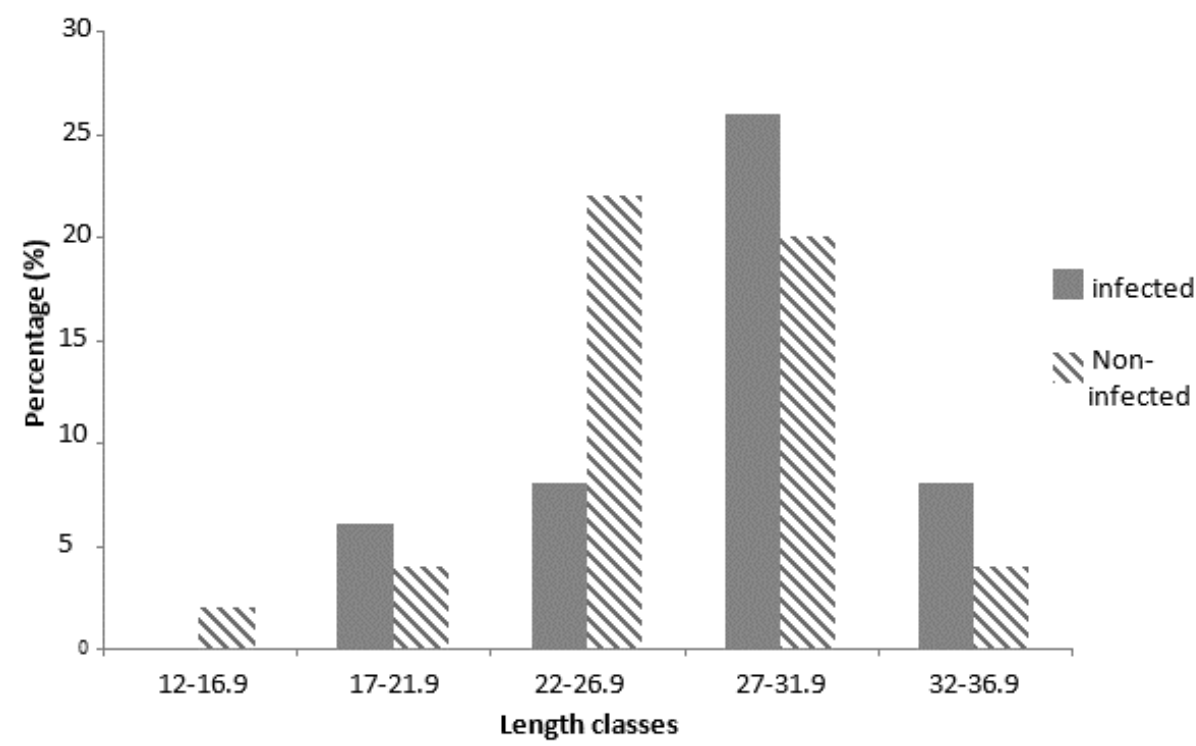

Figure 6. Percentage (\%) frequency of infestation and Non-infested Parachanna. obscura 


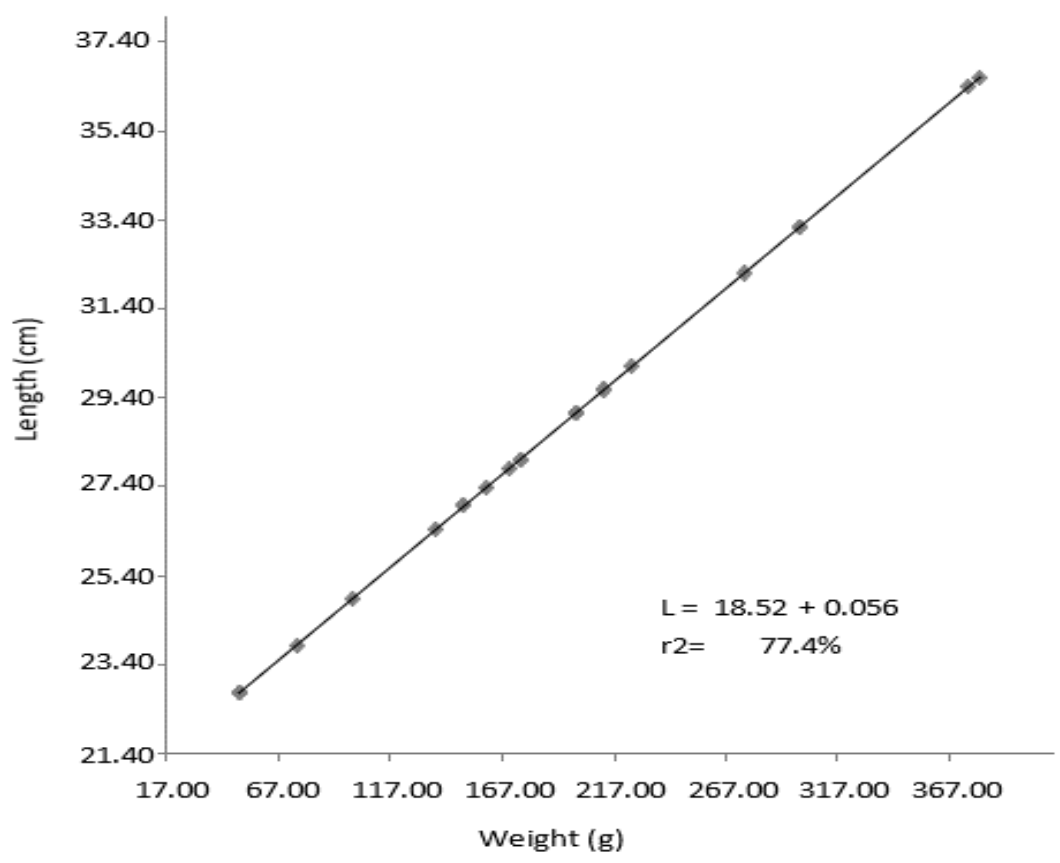

Figure 7. Length against weight of Infested Parachanna obscura.

non-infested as shown in table 1 . Percentage of incidence of infestation was $60 \%$ with the size groups ranging from $17 \mathrm{~cm}$ to $21.9 \mathrm{~cm}$.

The size groups $17-21.9 \mathrm{~cm}, 22-26.9 \mathrm{~cm}, 27-31.9 \mathrm{~cm}$ and $32-36.9 \mathrm{~cm}$ respectively had an average of 1.33 , 2.75, 2.25 and 2.0 nematodes per fish. Oden, Ama-Abasi and Ndome (2015) observed 12 worms per fish in the dry season and 6 worms per fish in the wet seasons as variations in incidence of nematode parasite on snakehead of the lower Cross River with no variation with size. In the present study, the parasitic load was on the weakest or most vulnerable part (anal pore having $61.7 \%$ of nematodes) followed by the intestine (29.8\%) while cardiac and caecum had $4.3 \%$ each which is opposed to Oden, et. al., (2015), Moravec (2000) and Ibiwoye, et al., (2006) who rather had the highest occurrence at the gut though they never examined the anal region. The World Book Encyclopedia (1994) reported that researchers have found more than 90,000 nematodes in a single rotting apple which goes to confirm why the concentration around the anus (smelling region). The incidence of parasitism decreased with size of Parachanna with $22-26.9 \mathrm{~cm}$ having 2.75 followed by $27-31.9 \mathrm{~cm}$ having 2.25 and then $32-36.9 \mathrm{~cm}$ with 2.0. Invariable no defined pattern was followed because at $12-16.9 \mathrm{~cm}$ length group the incidence was as low as 1.33. Conversely, the incidence of parasitic infestation may increase or decrease with size since other factors like nutrition, age and environment (presence of other parasites, water temperature and pollution, etc) could increase or lower the parasitic load.

The highest prevalence rate $(66.7 \%)$ of infestation in Parachanna obscura was obtained with the length class $(32-36.9 \mathrm{~cm})$ followed by $60 \%$ for length class (17-
$21.9 \mathrm{~cm}$ ) while the length class $(22-26.9 \mathrm{~cm})$ had the least prevalence rate of $26.7 \%$ as shown in table 1 and 2 . Length-class-wise, three out of every five Parachanna of the length size $17-21.9 \mathrm{~cm}$ were infested, 4 out 15,13 out of 23 , and 4 out of 6 , respectively, at $22-26.9 \mathrm{~cm}, 27-$ $31.9 \mathrm{~cm}$ and $32-36.9 \mathrm{~cm}$ group were infested with nematodes. Prevalence based on population referred to the number of nematodes in a particular length group over the total Parachanna population (50). Thus prevalence did not follow any regular pattern with length. Akther, Hakkani, Ashaduzzaman and Mohanta (2017) stated that prevalence of infection of parasite vary considerably depend on seasons, environment and management practices. Both Gado, Mahfouz, Moustafa and Lolo (2017) and Khan, Khartoon, Muhammad and Shafi (2019) observed that prevalence of some ecto. parasitic diseases in African catfish and fish Johniuss dussumieri were also seasonally dependent. Gado, et al., (2017) had $15.5 \%$ and $15 \%$ as highest prevalence of infestation of ectoparasites on Clarias gariepinus in both autumn and winter and spring and summer periods respectively while Akther. et al., (2017) had prevalence rates ranging from $4.5 \%$ in the stomach to $48.04 \%$ on the skin and monthly prevalence range from $50 \%$ to $92.30 \%$ on Channa punctatus. Oladipo, et al., (2019) and Sorour and Hamouda (2019) got varying prevalent rates ranging from $11 \%$ and $60.32 \%$ on Gnathonemus senegalensis (Trunkfish) and 0.55 to $100 \%$ on C. gariepinus by different ecto- and endo-parasites.

Infected blood of Parachanna obscura revealed oval, penial shape and Bi-concave Red cells. The Red cells appeared in clusters and the Lymphocytes were not normal, while the Non-infested blood of $P$. obscura, both the. Red cell and the Lymphocyte appeared normal 
The results of haematological characteristics of Parachanna obscura are as shown in Table 2. The value of pack cell volume (PCV \%) was higher for non-infested than infested $P$. obscura. It ranged from 12 to $33 \%$ and 17 to $31 \%$ for infested and non-infested respectively. The mean total PCV were 20.84 and $21.6 \%$ for infected and non-infested. This reduced value on the infested portends negative signal to the aquaculturist who should guard against any further loss of blood by employing some chemotherapeutic measures (Obiekezie, \& Ajah, 1994).

The mean lymphocyte ranged from 21 to $65 \%$ and 21 to $76 \%$ for infected and non-infected Parachanna obscura respectively. The overall mean lymphocyte for infested and non-infested $P$. obscura was $44.38 \%$ to $39.3 \%$ respectively. Such sudden rise from $39.3 \%$ to $44.38 \%$ is an indication that the fish is fighting an infection which causes the lymphocytes to multiply rapidly thereby producing characteristic swelling of the lymph. At this point the aquaculture candidate is at the risk of survival or at the least loses in economic value. The value on mean monocyte ranged from 0 to $6 \%$ for non-infested and 0 to $5 \%$ for infested $P$. obscura with overall mean of $1.9 \%$ and $1.92 \%$ for non-infested and infested respectively. Monocytes as a type of leucocytes (white blood cells) that help to build immunity in fish. The slightly lower level in the infected shows that the fish's immunity level is being compromised and calls for urgent attention. The mean Eosinophils was very low and ranged from 0 to $7 \%$ in both infected and noninfested $P$. obscura. The overall mean Eosinophils was $1.58 \%$ for infested and $1.2 \%$ for non-infested. The increase in level of Eosinophil being one of the combatants against parasitic infection could most likely be to cub the infection rate in Parachanna. The value of mean Neutrophils ranged from 24 to $78 \%$ for infested $P$. obscura. as against 33 to $76 \%$ for non-infested. The overall mean Neutrophils were $57.5 \%$ and $51.67 \%$ for non-infested and infested $P$. obscura respectively. The mean Leucocyte $\left(* 10^{3} \mathrm{~mm}^{-3}\right)$ was 4.18 for infested and 4.48 for non-infested $P$. obscura with a range from $3.4-$ 5.4 for infested and 2.4 to 6.2 for non- infested $P$. obscura. The lower the neutrophilic value, the lower the immunity level.

The mean condition factor $(k)$ was higher as the fish length increased with infestation being (0.71) slightly lower than that of the non-infested fishes (0.82) (Figure 6). The lower condition factor shows reduced immunity Nazeef and Abubakar (2013) opined that $k$ below one is not good. Coincidentally, the infected had $\mathrm{k}$ below one showing reduced wellness probably due to parasitic infection.

The test of means using anova amongst the infested showed positive linearity only between Lymphocyte and Eosinophils $\left({ }_{23} \mathrm{~F}_{0.022} ; 6.279\right)$ and between Leucocytes and Monocytes $\left({ }_{23} \mathrm{~F}_{0.073} ; 3.620\right)$. Deviations from linearity were 0,353 and 0.530 respectively. The rest did show any form of homogeneity. Besides, none of the pairs showed any positively significant $(P<0.05)$ skewness - change or alteration in any particular direction.

Table 2 shows the correlation coefficient between all the haematological parameters in both the infested and non-infested Parachanna. None of the parameters showed any positive significant difference between infested and non-infested. However, when one parameter in either infested was compared to noninfested, Leucocyte in infested had moderate positively $(P<0.05) \quad$ significant correlation with infested Neutrophils while PCV2 vs Lym2 had mild positive significant correlation $(P<0.05)$. Parameters with mild negative significant correlation at 0.05 level ( 2 tailed test) included Leu2 vs Neu2, Leu2 vs Lym2, Leu1 vs Lym1, PCV1 vs Lym1, PCV2 vs Neu2, Mono1 vs Mono2 Lym1 vs Eosino1. At $\alpha=0.01$ and 0.001 only the following had very strong negative significant correlation-Neu1 vs Lym1, Neu2 vs lym1, and Neu2 vs Lym2. The positive correlation implies that as one parameter goes up the other rises whereas with the negative correlation means that a decrease in a parameter results to commensurate decrease in the value of the other. Highly positive significant correlation $(P<0.01 ; 0.9255)$ existed between length and weight of $P$. obscura (Figure 7) which was very high for infected than non-infected Parachanna obscura. Correlation between length and condition factor $(k)$ was negative (Figure 5). Other correlations, that is, between Length and Leucocyte, Length and PCV, Weight and Leucocytes were positive but very poorly correlated. This study agrees with Boon, Zuxu and. Boom (1990) that parasitic infections reduced the PCV and Leucocyte values. This work also corroborates with Adebayo, et. al., (2007) where the Leucocytes value showed a negative correlation with PCV. Intensification of infestation and hence higher degree of infections evidenced by lower pcv, leucocytes and neutrophils, will invariably, not only reduce the immunity but will also lower the economic values of the aquaculture candidate.

The blood analysis of infected and non-infected Parachanna obscura presented in table 1 based on the 50 fish samples showed a slight variation in their haematological values. These variations may be attributed to the presence of parasites (nematodes). In some of these specimens it was observed that those fish harbouring nematodes weighed more than the noninfested ones and the incidence of infestation was highest for length classes $22 \mathrm{~cm}$ to $32 \mathrm{~cm}$ probably due to increase in size of the specimens. The abundance of these length classes may be attributed to the selectivity of the gear being used especially in the swamps/tributaries where the species were more abundant. Garcia, Echevarrin, Martinez, and Zamora, (1992), opined that fish size can cause variation in haematological values.

The effects of nematode infestation in Parachanna obscura were pronounced in parameters 
such as Pack cell volume (PCV), Lymphocyte, Monocytes, Eosinophills, Leucocytes and Neutrophills. It has been observed that the PCV was lower in infested (20.8\%) than non-infested $(21.6 \%)$ specimens and tend to increase with length and weight. The parasitic effects of nematode on fish can result in anaemic condition in the fish. This situation was a reverse of Lymphocytes which were higher in infested $(44.38 \%)$ than non. infested (39.3\%) $P$. obscura. The present study established the fact that as the level of parasitic infestation increased, the PCV reduced and caused variation in blood index values. Besides, the previous studies by Lavanya, et al., (2011); Pradhan, Patra, Mohanty, and Pal (2012); Pradhan, Patra, and Pal (2014); and George, Akinrotimi, and Nwokoma (2017) attributed such variations to factors such as age, fish size, nutritional state, season (Pradhan, et al., 2012), spawning, sex (Collazos, Ortega, Barriga, \& Rodriguez, 1998), malnutrition (Ighwela, Ahmad, \& AbolMunafi, 2012), environmental stress (Singh \& Tandon, 2009; Ahmed \& Sheikh, 2020), and genetic variation in different fish species, parasitic infestation is hereby implicated.

The presence of Neutrophills caused more serious stress in the infested (51.7\%) than non-infested (57.5\%) Parachanna obscura because it provided the fish with defense against invading nematodes, a process known as chemotaxis. The Leucocyte was lower in infested $\left(4.18 \times 10^{3} \mathrm{~mm}^{-3}\right)$ than non-infested $\left(4.48 \times 10^{3} \mathrm{~mm}^{-3}\right) P$. obscura. This is understood because the leucocytes in infested $P$. obscura are always engaged in defending the fish against foreign bodies and in the process may be destroyed. George, et al., (2017) observed that the introduction of two pesticides-atrazine and metolachlor to Clarias gariepinus resulted in significantly higher positive difference over the control in white blood cell (WBC), neutrophils, monocytes, mean corpuscular haemoglobin (MCH) and mean corpuscular haemoglobin concentrations (MCHC). Jerônimo, et al., (2014), stated that hematological alterations might be related to physiological characteristics as well as disease or culture conditions. They added that in the hostparasite relationship, the severity in health alterations might be associated to attachment mechanisms of the parasite, its life cycle and mainly, the number of parasites.

\section{Conclusion}

The haematological parameters - Pack cell volume $(\%)$, Leucocyte (\%), Monocyte (\%), Eosinophills and Neutrophills (\%) values were lower in the infested while the Lymphocyte (\%) was higher in the non-infected $P$. obscura specimens obtained from Great Kwa Rivers, Cross River estuary depicting the extent of damage parasitic nematode had on $P$. obscura. More parasites constituting, $61.7 \%$ and $29.8 \%$, respectively, were found in the fish anal pore and intestine whereas only $4.3 \%$ were each found in the cardiac and caecum region. This study creates awareness of the probable negative impart parasite infestation could have on the fish industry, hence the obvious need to administer prophylactic treatment or chemotherapeutic when already manifested. Prevalence and incidence of infestation moved in opposite direction in $P$. obscura. The immune system of Parachanna were affected negatively due to parasitic infestation exemplified by the reduced values amongst key parameters like Neutrophils, leucocytes and PCV etc in infested compared with non-infested. The aquaculture implication of such reduction is low immunity and economic losses to the fish farmer.

\section{References}

Adebayo, O.T., Fagbenro, O.A., Ajayi, C.B. \& Popoola, O.M. (2007). Normal haematological profile of Parachanna obscura as a diagnostic tool in aquaculture. International Journal of Zoological Research, 3, 193-199.

Adeyemo, O.K., Okwilagwe, O.O. \& Ajani, F. (2009). Comparative assessment of sodium edta and heparin as anticoagulants for the evaluation of haematological parameters in cultured and feral African catfish (Clarias gariepinus). Brazilian Journal of Aquatic Science and Technology, 13(1), 19-24.

Ahmed, I \& Sheikh, Z. A. (2020). Comparative study of hematological parameters of snow trout Schizopyge plagiostomus and Schizopyge niger inhabiting two different habitats, The European Zoological Journal, 87,1,

12-19. http://dx.doi.org/10.1080/24750263.2019.1705647

Ajah P.O., \& Ukutt, E.R. (2018a). The in vitro effect of water soluble fraction of crude oil on the biochemical, hematological and enzymological parameters of clariid catfish juveniles and sub adults. International Journal of Scientific and Engineering Research (IJSER), 9(12),13641385.

Ajah P.O., \& Ukutt, E.R. (2018b). The effect of water-soluble fraction of crude oil on the biochemical, hematological and enzymological changes in fed and starved clariid catfish juveniles. International Journal of Scientific and Engineering Research (IJSER), 9(4), 1386-1406.

Akther, S., Hakkani, E. Aman, A \& Mohanta, M. (2018). Prevalence of parasitic infestations in the freshwater fish, Chann punctatus (Bloch) from Rajshahi Metropolitan, Bamgladesh. International Journal of Current Microbiology and Applied Sciences, 7(04), 34313441. DOI: 10.20546/ijcmas/2018.704.388.

Ama-Abasi, D., \& Anthony, O. (2010). Proximate analysis of snakeshead, Parachanna obscura, (Gunter 1861) in the Cross River, Nigeria. Global Journal of Agricultural Sciences, 9(2), 7-13.

Anderson, D., \& Klontz, G.W. (1965). Basic Haemotology for the fish culturist Ann. Northwest. Fish cult., 16, 38-41.

Bassey, A.U. \& P.O. Ajah (2010). Effect of three feeding regimes on growth, condition factor and food conversion rate of pond cultured Parachanna obscura (Gunther, 1861) (Channidae) in Calabar, Nigeria. Turkish Journal of Fisheries and Aquatic Sciences, 10, 195-202.

Boon, J.H., Zuxu, Y. \&. Boom, G.H.R (1990). Effects on Anguillicola crassus and Trypanosoma granulosum 
infections on peripheral blood cells of European Eel (Anguilla anguilla L). Bull. Eur. Ass. Fish Pathol., 10 (5), 143-145.

Clauss, T.M., Alistair, D.M. \& Arnold, J.E. (2008). Hematological disorders of fish. Veterinary Clinics of North America: Exotic Animal Practice, 11(3), 445-462.

Collazos, M.E., Ortega, E., Barriga, C. \& Rodriguez, A.B. (1998). Seasonal variation in hematological parameters male and female Tinca tinca, Molecular and Cellular Biochemistry, 183(1-2), 165-168. http://dx.doi.org/10.1023/A:1006878922332

Conver, D F. Spadling, M.G. \& Forester, D.J. (2003). Epizootiology of Eustrongylides ignotus in Florida: Transmission and development of larvae in intermediate hosts. Journal of Parasitology, 89(2), $290-298$

Dacie, J.V. \& Lewis, S.M (1984). Practical Haematological $8^{\text {th }}$ edition Edinburgh, Livingstone. 50 - 57.

Gado, M.S.M., Mahfouz, N.B., Moustafa, E.M.M. \& Lolo, E.E.E. (2017). Prevalence of some ectoparasitic diseases in African catfish (Clarias gariepinus) at Kafr El-Sheikh governorate. International Journal of Fsheries and Aquatic Studies, 5(3), 576-583.

Garcia, M. P., Echevarrin, G., Martinez, F. J. \& Zamora, Z., (1992). Influence of blood sample collections on the haematocrit value of two teleosts, rainbow trout (Oncohrhynchus mykiss) and European sea bass (Dicentrachus labrax L.). Comp. Biochem.Physiol., 101, 733-736.

George, A.D.I., Akinrotimi, O.A. \& Nwokoma, U.K. (2017). Haematological Changes in African Catfish (Clarias gariepinus) Exposed to Mixture of Atrazine and Metolachlor in the Laboratory, Journal of Fisheries Science.com, 11(3), 048-054.

Gupta, S., \& Banerjee, S. (2011). Assessment of some haematological parameters of an airbreathing fish Heterpneustes fossilis-After short term exposure to sublethal concentrations of Mercuric Chloride. Fishing Chimes, 31(8), 1-4.

Guseva, L.N. (1990). Food Diets and feeding ratio in snakehead Channa argus in the lower A muder's ya R. J. Ofo. Lethy Oil, 30, 439-466.

Ibiwoye, T.I.I., Owolabi, O.D., Ajala, A.A., Oketoki, T.O., Adio, S.M., Adedapo, A., Ayeku, P.O. \& Agbontale, J.J. (2006). Helminth parasites in freshwater fish species from Jebba Lake and Bida floodplain areas of River Niger, Nigeria. Proceedings of Conference of the Fisheries Society of Nigeria, 16(20), 13-20.

Ighwela, K. A.; Ahmad, A. B. \& Abol-Munafi, A. B., (2012). Haematological changes in Nile tilapia (Oreochromis niloticus) fed with varying dietary maltose levels. World J. Fish Mar. Sci.4. 376-381.

Imanpoor, M.R., Bagheri, T., \& Hedayati, S.A.A. (2010). The anaesthetic effects of clove essence in persian sturgeon, Acipenser persicus. World Journal of Fish and Marine Sciences, 2(1), 29-36.

Jerônimo, G.T., Pádua, S.B., Bampi, D., Gonçales, E.L.T., Garcia, P., Ishikawa, M.M., \& Martins, M.L. (2014). Haematological and histopathological analysis in South American fish Piaractus mesopotamicus parasitized by monogenean (Dactylogyridae). Brazilian Journal of Biology, 74(4), 1000-1006. http://dx.doi.org/10.1590/1519-6984.09513.

Khan, R.K, Khatoon, N., Muhammad, F., \& Shafi, M. (2019). Seasonal variation of parasitic infections in fish Johniuss dussumieri (Perciformes: Sciaenidae). International
Journal of Aquatic Science, 10(2), 94-97. ISSN: 20088019.

Kori-Siakpere, O. \& Egbor, V.E. (1997). Haematological characteristics African mudfish: Clarius buthupogon (Clariidae), Bul., 21, $177-185$.

Kori-Siakpere, O., Ake, J.E.O. \& Idoge, E. (2005). Haematlogical characteristics of the African snakehead, Parachanna obscura, African Journal of Biotechnology, 4(6), 527-530.

Kumari, A., \& Perven, S. (2017). Comparative study of helminth parasites in freshwater fish, Channa punctatus of Chapra, Bihar. International Journal of Scence and Research, 6(8), 1369.

Lavanya, S.; Ramesh, M.; Kavitha, C. \& Malarvizhi, A., (2011). Hematological, biochemical and ion regulatory responses of Indian major carp Catla catla during chronic sub lethal exposure to inorganic arsenic. Chemosphere, 7, 977-985

Lewis, S.M. \& Ward, P.G. (1975). An evaluation of Haematological Laboratory Practice. 24:13

Labello, S.L., Saunder, D.K. \& Crawford, T.G. (2001). Observation on the blood viscosity in striped bass, Morore saxatilis (Coal baum) associated with fish hatchery condition Transaction of the Kansas Academy of Science, 104 (314), $183-194$

Margolis, L., Esch, G.W., Holmes, J.C., Kuris, A.M., \& Schad, G.A. (1982). The use of ecological terms in parasitology (Report on an ad.hoc committee of the American Society of Parasitologist). Journal of Parasitology, 68, 131-133.

Mazumder, S.K., Fivelstad, S., Ghaffar, M. Abd., \& Das, S.K. (2019). Haematological and biochemical responses of juvenile Malabar blood snapper (Lutjanus molabaricus Bloch \& Schneider, 1801) exposed to different rearing temperatures and diets. Sains Malaysiana, 48(9), 17901810. http://dx.doi.org/10.17576/jsm-2019-4809-01

Moravec, F. (2000). Nematodes of the freshwater fishes of the Neotropical region. Folia Parasitologia, 47, 60-66.

Nazeef, S, \& Abubakar, U.M. (2013). Diversity and condition factor of fish species of DadinKowa Dam, Gombe State, Nigeria. Greener Journal of BiologicalSciences, 3(10), 350-356.

Obiekezie, A.I. \& Ajah, P. O. (1994). Chemotherapy of Macrogyrodactylosis in the culture of African clariid catfish: Clarias gariepinus and Heterobranchus longifilis. J. Aqua. in the Tropics, 9, 187-192.

Oladipo, S.O., Sunday, O.J., \& Ogunbiyi, D.C. (2019). Occurrence and prevalence of parasites associated with Gnathonemus senegalensis in Apodu Reservoir, Malete, Nigeria. Sri Lankan Journal of Biology, 4(1), 14-23.

Pradhan, S. C.; Patra, A. K.; Mohanty, K. C.; \& Pal, A., (2012). Hematological and plasma biochemistry in Cirrhinus mrigala (Hamilton 1822). Comp. Clin. Pathol., http://dx.doi.org/10.1007/s00580-012-1642-z.

Pradhan, S.C., Patra, A.K. \& Pal A. (2014). Hematological and plasma chemistry of Indian major carp, labeo rohita (Hamilton, 1822). Journal of Applied Ichthyology, 30(1), 48-54. http://dx.doi.org/10.111/JAl.12297

Satheeshkumar, P., Ananthan, G., Senthil Kumar, D. \& Jagadeesan, L. (2010). Haematology and biochemical parameters of different feeding behavior of teleost fishes from Vellar estuary, India. Comp Clin Pathol http://dx.doi.org/10:1007/s00580-011-1259_7.

Singh, B.P. \& Tandon, P.K., (2009). Effect of river water pollution on hematological parameters of fish, Wallago attu. Res. Environ. Life Sci,.2, 211-214. 
Sorour, Sh., \& Hamouda, A.H. (2019). Prevalence of nematode infestation in Clarias gariepinus from El-Burullus Lake and Lake Nasser, Egypt. Iraqi Journal of veterinary Sciences, 33(2), 181-188.

Smith, C.G., Lewis, W.M., \& Kaplan, H.M. (1952). A Comparative morphologic and physiologic study of fish blood. Prog. Fish Cult., 14, $169-172$.

Teugels, G.G., Breine, J.J. \&Thys Van den Audernaerde, D.F.E. (1984). Channidae. In: J. Daget, J.P. Gosse and D.F.E. Thys van den Anderaerde (Eds) Checklist of the Freshwater Fishes of Africa (CLOFFA). ORSTOM Paris and MRAC, Tervuren: 288-290.
Teugels, G.G., Reid, G.M. \& King, R.P. (1992). Fishes of the Cross-River Basin (Cameroon, Nigeria) taxonomy, zoogeography, ecology and conservation: Tervuren, Belgique, Muse Royal de LAfrique Central, Annales Sciences Zoologiques, 266: 132.

The World Book Encyclopedia (1994). Volume 16, p.491. ISBN 0.7166-0094-3. USA

Witeska, M. (2005); Stress in fish-haematological and immunological effects of heavy metals, Electronic of Icthyology, 1, 35-41. 